\title{
Proto-kimberlitic ultra-deep diamonds from Collier 4 kimberlite pipe, Juina, Brazil.
}

\author{
G.P. Bulanova ${ }^{1}$, C.B. Smith ${ }^{2}$, M.J. Walter ${ }^{1}$, J. Blundy ${ }^{1}$, L. Gobbo ${ }^{3}$, EIMF ${ }^{4}$, S.C. Kohn ${ }^{1}$. \\ ${ }^{I}$ University of Bristol, U.K., \\ ${ }^{2}$ Rio Tinto Mining and Exploration Pty. Ltd., London, U.K., \\ ${ }^{3}$ Rio Tinto Desenvolvimentos Minerais Ltda., Brasilia, Brazil, \\ ${ }^{4}$ Edinburgh Ion Microprobe Facility, University of Edinburgh, U.K.
}

Collier 4 kimberlite pipe, located within the Cretaceous (91.6-94.6 Ma) Juina Kimberlite Field, is one of the possible primary kimberlite sources for the ultra-deep inclusion-bearing alluvial diamonds previously studied from the Rivers Sao Luiz and Sorriso (e.g. Harte et al., 1999, Kaminsky et al., 2001, Hayman et al., 2005).

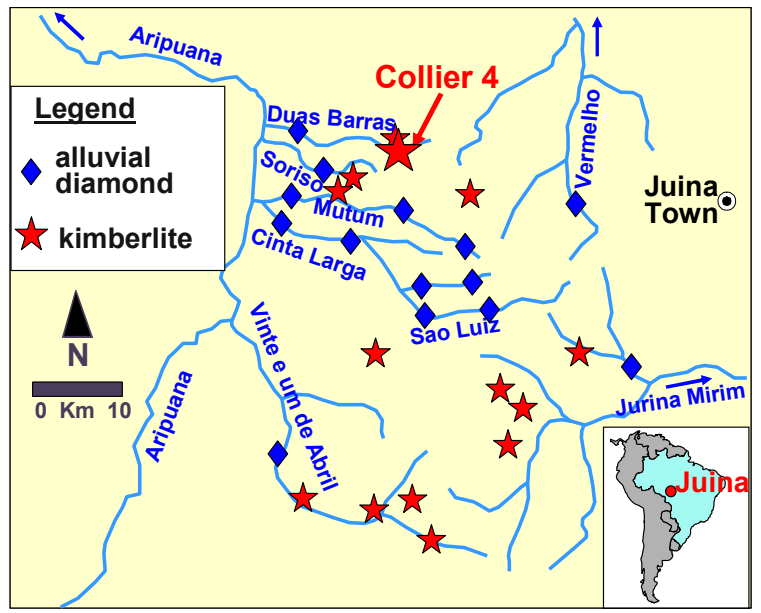

Fig. 1. Map of Juina Diamond field.

The Field is situated near the northern border of the Palaeozoic Parecis Basin and is underlain by the Mesoproterozoic sialic Rio Negro-Juruena Mobile Belt developed during tectonothermal reworking along the southern margin of the Amazon Craton.

The Juina Field is one of the many expressions of Cretaceous alkaline volcanicity developed along the $\mathrm{AZ} 125^{\circ}$ lineament ascribed to the passage of the Brazilian continent over the Trindade Plume. The disputed geological evolution of the Rio Negro Juruena Mobile Belt (lateral versus vertical accretion?) results in controversy over Juina's kimberlite geotectonic setting ("on-craton" or "off craton"). Eclogites and garnet lherzolites are the most abundant mantle xenoliths in the kimberlites and have been dated at ca. 1.6 Ga (Costa et al., 2003), suggesting a link to Mesoproterozoic subduction of oceanic crust during formation of the Mobile Belt.

\section{Methods and samples}

30 diamonds with mineral inclusions were selected for study under optical microscope from a Rio Tinto collection. The diamonds are $2-3.5 \mathrm{~mm}$ in size colourless or brown transition forms and more rare octahedrons and dodecahedrons; some macles and aggregates present. Most of the crystals are broken, heavily resorbed, plastically deformed and have internal cracks and deep etch channels (Fig. 2).

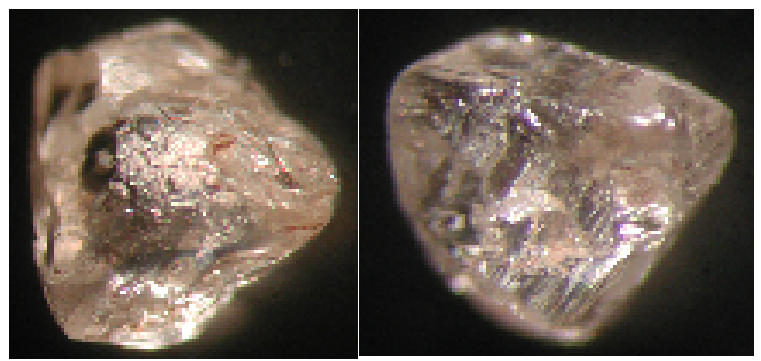

Fig. 2. Diamonds J1 and J2 (width 3.5 and 2.5mm)

The diamonds were polished for producing parallel central plates and exposing inclusions and studied by PL, CL, FTIR, SEM, EMP and SIMS methods.

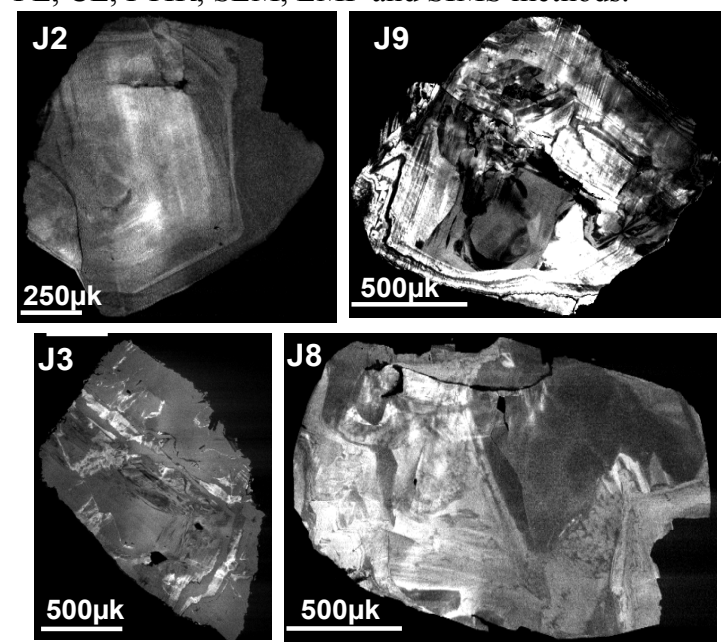

Fig. 3. CL images of some Collier4 diamonds.

CL imagery of the diamonds (Fig 3) displays their complex internal structure: deformations and stresses, breakages and resorption. 
All but two diamonds studied are N-free type II. J7 stone has $66 \mathrm{ppm} \mathrm{N}$ which is completely aggregated type $1 \mathrm{aB}$ and $\mathrm{J} 3$ diamond contains moderate $\mathrm{N}$ concentration and is type $1 \mathrm{aA}-1 \mathrm{aB}$ (Table 1$)$.

\section{Chemistry of inclusions}

The syngenetic diamond inclusions have eclogitic-style chemistry (Table 1).

Table 1 Collier 4 diamond inclusion paragenesis

\begin{tabular}{|c|c|c|c|}
\hline $\begin{array}{l}\text { Ds } \\
\text { No }\end{array}$ & FTIR & Syngenetic inclusions & $\begin{array}{c}\begin{array}{c}\text { Parage- } \\
\text { nesis. }\end{array} \\
\end{array}$ \\
\hline $\mathrm{J}-1$ & type II & CaTi-prv+CaSi-prv; Po; Majorite & UD \\
\hline $\mathrm{J}-2$ & type II & "Ca-epidote"+Ky; Fe; MgFeAl-spinel; Gt & UD \\
\hline $\mathrm{J}-3$ & $1 \mathrm{aA}-1 \mathrm{aB}$ & Six Cpx; CaMgFeAl-phase & $\mathrm{E}$ \\
\hline $\mathrm{J}-4$ & type II & Gt; Carbonate micro-inclusion & $\mathrm{E}$ \\
\hline $\mathrm{J}-5$ & type II & Po+Mgt; $\mathrm{SiO}_{2}$ & E (UD?) \\
\hline $\mathrm{J}-6$ & type II & Fe-Cu-sulphide & E (UD?) \\
\hline $\mathrm{J}-7$ & $1 \mathrm{aB}+\mathrm{PI}$ & Fe-Cu-sulphide & E (UD?) \\
\hline $\mathrm{J}-8$ & type II & Cpx+"Mg-epidote"-phase; $\mathrm{SiO}_{2} \mathrm{Po}+\mathrm{FeO}$ & UD \\
\hline $\mathrm{J}-9$ & type II & Majorite & UD \\
\hline $\mathrm{J}-10$ & type II & CaTi+CaSi-prv; Po. & UD \\
\hline $\mathrm{J}-11$ & no data & Not identified black microinclusions & unknown \\
\hline $\mathrm{J}-12$ & no data & Not identified black microinclusions & unknown \\
\hline $\mathrm{J}-13$ & type II & K-Al-Mg-Fe-Ti-Si- micro-inclusion & unknown \\
\hline $\mathrm{J}-14$ & no data & Two CaSi-prv inclusions & UD \\
\hline $\mathrm{J}-15$ & no data & Po & $E$ \\
\hline $\mathrm{J}-16$ & no data & Po & $E$ \\
\hline $\mathrm{J}-17$ & no data & $\mathrm{SiO}_{2}$ & E (UD?) \\
\hline $\mathrm{J}-18$ & type II & $\mathrm{Fe}+\mathrm{FeO}$ & unknown \\
\hline $\mathrm{J}-19$ & no data & $\mathrm{SiO}_{2}+\mathrm{Ky}$ & E (UD?) \\
\hline $\mathrm{J}-20$ & type II & "Ol"; Ca-Mg-Fe-Al-carbonate micro-incl. & UD \\
\hline
\end{tabular}

Among them the ultradeep paragenesis comprises: $\mathrm{CaSi}$-perovskite $\pm \mathrm{CaTi}$-perovskite, Ca-majorite, $\mathrm{SiO}_{2}$ and "olivine" (former wadsleyite). This silicate phases association is stable in the Transition Zone (TZ) according to experimental results.

The majoritic component in the Collier 4 garnets is low and gives equilibration pressure of 7-10 GPa (Fig .4).

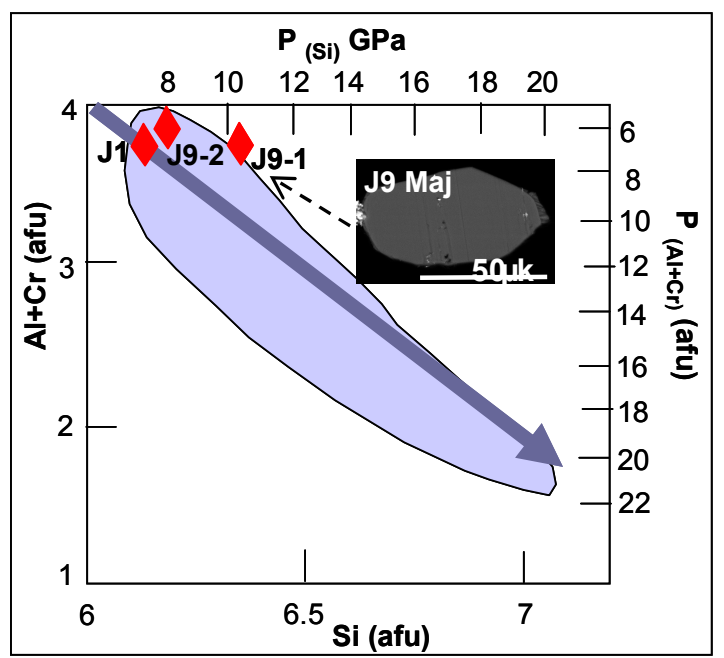

Fig. 4. $(\mathrm{Al}+\mathrm{Cr})$ vs Si per atomic formula unit (afu) in majorite inclusions from diamonds $\mathrm{J} 1$ and $\mathrm{J} 9$.

The composite inclusions of $\mathrm{CaTiO}_{3}+\mathrm{CaSiO}_{3}$ in two diamonds are interpreted as retrograde exsolution phases from a complete perovskite solid solution which, according to experimental data, exists at pressure $>12 \mathrm{GPa}$ in the $\mathrm{TZ}$ or Low Mantle (LM) (Kubo et al., 1997).

Fig. 5. SEM images of two-phases inclusion "Ca-epidote" + kyanite and native iron inclusion from diamond $\mathrm{J} 2$.

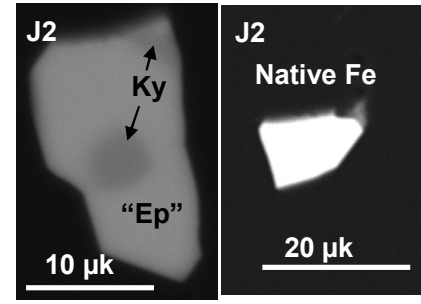

The mineral assemblage: eclogitic garnet, "Ca-epidotephase"+ kyanite, MgFeAl-spinel and native iron found in one diamond (Fig. 5) is probably also ultradeep but re-equilibrated into lower PT phases during transportation to the surface. The "epidote-phase" is similar in composition to natural epidote and to the experimental aluminium rich phase of high PT conditions of the TZ and LM, such as NAL (Miyajima et al., 2001). NAL formula is: $\left[(\mathrm{K}, \mathrm{Na}, \mathrm{Ca})_{1}(\mathrm{Mg}, \mathrm{Fe})_{2}\right]_{3}$ $(\mathrm{Al}, \mathrm{Si})_{5.5-6.00} \mathrm{O}_{12}$ The "Ca-epidote" diamond inclusion has a MORB-type geochemical signature indicating an input of subducted material into the deep mantle.

"Olivine" identified in one diamond is Fo 90 and contains $0.19 \mathrm{NiO}, 0.05 \mathrm{Al}_{2} \mathrm{O}_{3}, 0.03 \mathrm{Cr}_{2} \mathrm{O}_{3}, 0.14 \mathrm{CaO}$ and $0.03 \mathrm{Na}_{2} \mathrm{O}$ wt \%, indicative of origin in the $\mathrm{TZ}$ or Low mantle (Brey et al, 2004). Compared with Upper mantle olivines there is also a high $\mathrm{MnO}$ concentration in this inclusion $(0.17 \mathrm{wt} \%)$.

Upper Mantle eclogitic inclusions comprise Ti-Caalmandine-pyrope $\mathrm{G} 4$, omphacite, kyanite, $\mathrm{SiO}_{2}$ and low-Ni sulphides. Low Ni-sulphides are common; some micro-inclusions of $\mathrm{Ca}-\mathrm{Fe}-\mathrm{Mg}$ carbonates and iron of undistinguished paragenesis were also found.

The trace element chemistry of J9 majorites is similar to those summarised by Stachel (2001). Majorite J1 is exceptional because the highest concentration of REE ever reported (Fig. 6). Diamond J1 contains a twoperovskite inclusion where both $\mathrm{CaSi}$ - and $\mathrm{CaTi}$-phases also have the highest content of REE compared with

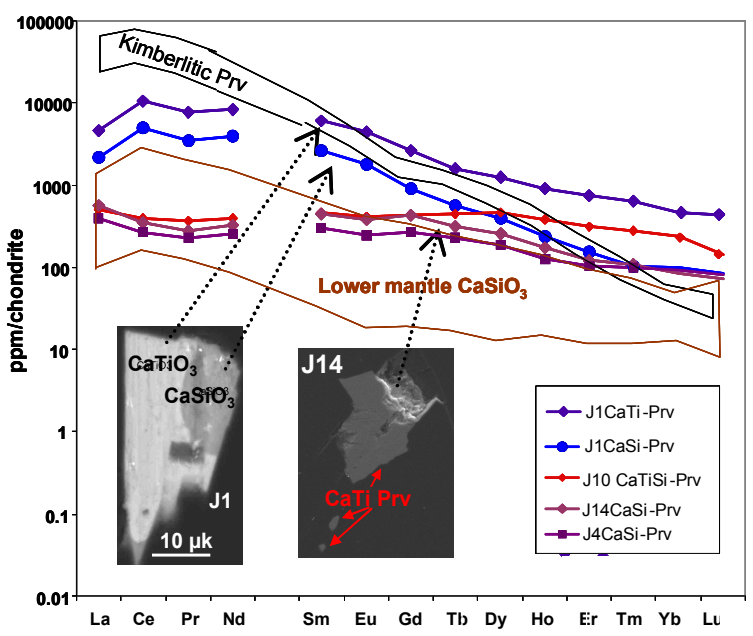

Fig 6. Chondrite normalised REE in the Collier 4 perovskite diamond inclusions. 
known previously (Walter et al., in press). Such enrichment of eclogitic environments by incompatible elements during diamond formation could be explained by metasomatic input of carbonatitic melt.

\section{Carbon isotope composition of diamonds}

The diamonds display a very wide range of carbon isotopes: from heavy mantle to lightest organic values (Fig. 7). J20 with "olivine" inclusion and two eclogitic stones with sulphides are in the heavy mantle group of $\delta^{13} \mathrm{C}-6$ to $-7.5 \%$. Similar values are found in three rim zones of diamonds with CaSi-perovskites and majorite inclusions, which cores started from much lighter $\delta^{13} \mathrm{C}$ of -9 to $-13.5 \%$ o. Diamonds with CaTiperovskites and some eclogitic stones show similar or no change in core-rim signatures and lie in the interval of subducted carbon of -12 to $-15 \%$ o $\delta^{13} \mathrm{C}$ (Fig. 7).

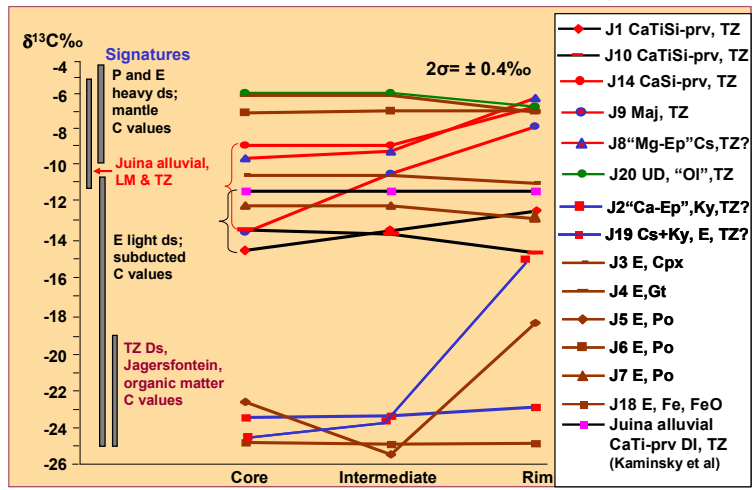

Fig. 7. Carbon isotope composition of Collier 4 diamonds in core - rim traverses.

The isotopically lightest diamonds contain kyanite, coesite and "Ca-epidote". Similar to the diamonds with CaSi-perovskite inclusions they show $\delta^{13} \mathrm{C}$ increasing during growth, which probably indicates their precipitation from a $\mathrm{CO}_{2}$-rich fluid. For crystals $\mathrm{J} 2$ and $\mathrm{J} 18$ such isotopic zonation is very abrupt, from core values of -23 to $-25 \%$ o to rim of -15 to $-17 \%$ o $\delta^{13} \mathrm{C}$.

The diamond core-signatures of extremely low $\delta^{13} \mathrm{C}$ are attributed to subducted organic matter and manifest nucleation of the diamonds in $\mathrm{TZ}$ horizons, where organic matter was not well mixed with isotopically heavy subducted carbonates. The rim zones were grown on other TZ levels where the two sources of subducted carbon were already mixed, resulting in the medium-light $\delta^{13} \mathrm{C}$ values. Such strong isotopic fractionation of a single carbon source during growth of one diamond is not a realistic process. The reason for this abrupt isotopic zonation in single crystals can be explained by diamond formation from different sources of carbon at different stratigraphic layers of the $\mathrm{TZ}$ to which the diamonds were uplifted or subducted.

Formation of the diamonds and mineral inclusions The phase relationships of the mineral inclusions and trace element chemistry show that they crystallised during different stages of differentiation of a diamondforming Ca-rich melt/fluids. Thus some $\mathrm{Ca}(\mathrm{Ti}, \mathrm{Si}) \mathrm{O}_{3}-$ perovskite and Ca-majorites coexisted with a primary partial melt of a carbonated eclogite that formed in the TZ. Other inclusions may have crystallized within the deep Upper Mantle from rising differentiated carbonatite melt. Efforts to date a $\mathrm{Ca}(\mathrm{Ti}, \mathrm{Si}) \mathrm{O}_{3}$ perovskite inclusion by $\mathrm{U}-\mathrm{Pb}$ by ion probe are suggesting a Cretaceous age, which is close to the kimberlite emplacement time. If the dating is correct the Collier 4 ultradeep diamonds are relatively young. Carbon isotope composition variation in core-rim traverses in single diamonds and phases of exsolution in the inclusions give evidence about the extensive scale of vertical movements of the diamond-forming system within the Earth. It is deep carbon recycling caused by processes of subduction and uplifting.

We consider the Collier 4 diamond protolith was partially-melted carbonated eclogite with diamonds formed from $\mathrm{CO}_{2}$-dominated fluids. Sulphide presence may have lowered the oxygen fugacity of the carbonate-silicate melt/fluid from which diamonds crystallised. The presence of native iron gives evidence of extremely reduced conditions suitable for diamond formation. The Collier-4 kimberlite magmatism and the ultradeep diamonds could both be considered genetic, temporal and geographic results of the Trindade Plume event.

\section{References}

Brey, G.P., Bulatov, V., Girnis, A., Harris, J.W., Stachel, T. Ferropericlase - a lower mantle phase in the upper mantle. 8th International Kimberlite Conference selected papers, 2004. 2, 647-663.

Harte, B., Harris, J. W., Hutchison, M. T., Watt, G. R. and Wilding, M. C. in Mantle Petrology: Field observations and high pressure experimentation (eds: Fei, Y., Bertka, C. M. and Mysen, B. O.) (Geochemical Society Special Publications, 1999), 125-153.

Hayman, P. C., Kopylova, M. G. and Kaminsky, F. V. Lower mantle diamonds from Rio Soriso (Juina area, Mato Grosso, Brazil). Contributions to Mineralogy and Petrology, 2005, 140, 734-753.

Kaminsky, F.V., Zakharchenko, O.D., Davies, R., Griffin, W.L., Khachatryan-Blinova, G.K., and Shiryaev, A.A. Superdeep diamonds from the Juina area, Mato Grosso State, Brazil. Contributions to Mineralogy and Petrology, 2001, 140: 734-753.

Nobuyoshi Miyajima, Takehiko Yagi, Kei Hirose, Tadashi Kondo, Kiuoshi Fujino, Hiroyuki Miura. Potential host phase of aluminium and potassium in the Earth's lower mantle. American Mineralogist, 2001, 86, 740746.

Kubo, A., Suzuki, T. \& Akaogi, M. High pressure phase equilibria in the system $\mathrm{CaTiO} 3-\mathrm{CaSiO} 3$ : stability of perovskite solid solutions. Physics and Chemistry of Minerals, 1997, 24, 488-494.

Stachel, T., Diamonds from asthenosphere and transition zone. European Journal of Mineralogy, 2001, 13, 883892.

Walter, M., Bulanova, G., Armstrong, L., Keshav, S., Blundy, J., Gudfinnsson, G., Lord, O., Lennie, Smith, C., Gobbo, L., and EIMF. 2008. Primary carbonatite melt from deeply subducted oceanic crust. Nature (in press). 